\title{
A comparative study of beach nourishment methods in selected areas of the coasts of the United Kingdom and The Netherlands
}

\author{
S. A. Walvin \& S. B. Mickovski \\ School of Engineering and Built Environment, \\ Glasgow Caledonian University, UK
}

\begin{abstract}
Combating coastal erosion and sea level rise puts constant pressure on local authorities and government departments to ensure cost effective and environmental sustainable practices are used and the outcomes of reducing flooding and erosion are achievable. This study assesses and compares the coast protection policies and practices at two case study locations in the southern North Sea: those of the Lincolnshire and Netherlands coastlines. The coastal policies of these two countries have been manipulated under repeated threat of disaster since the 1953 storm surge. The five year rolling Lincshore beach nourishment practice is considered against the innovative mega-nourishment sand-motor project of the South Holland coastline. The latter is expected to last for 20 years and so its cost effectiveness, efficiency and environmental sustainability is discussed and compared with the Lincshore programme. Rationale is provided on why mega-nourishment projects should be considered by all coastal bound local authorities and why the sand-motor is an effective and innovative option for coastal protection and environmental sustainability.

Keywords: beach nourishment, integrated coastal zone management, Lincshore, Netherlands, Norfolk.
\end{abstract}

\section{Introduction}

Coastal erosion, in conjunction with risk of flooding and habitat loss from climate change and sea level rise (SLR), combined with coastal squeeze from urban expansion and hard sea defences requires an efficient and sustainable management approach. With SLR predicted to increase approximately $20 \mathrm{~mm}$ 
[1] on top of the $200 \mathrm{~mm}$ rise over the last century [2], anthropogenic effects of applying hard sea defences can ironically exacerbate coastal erosion leading to an increase in coastal squeeze and subsequent habitat loss [2-4]. These impacts exert increased pressure on coastal managers on a global scale; such as in Florida [5], of hinterland flooding from SLR impacts. A similar situation is found along the Bangladesh coastal estuaries suffering from coastal erosion [6]. The case study locations of Lincolnshire, United Kingdom (UK) and South Holland in the Netherlands are significantly affected by coastal erosion and SLR. These areas are subject to a considerable threat of erosion, overtopping and inland flooding of up to $10 \mathrm{~km}$ inland in such areas as the Norfolk Broads and the Polder region around Den Hague. This is exacerbated in the low-lying areas that are on average five meters below sea-level [7].

Traditional coastal protection methods along the UK East coast, especially along the urbanised stretches of coastline are an expensive, time consuming, with a continuous cycle of maintenance and repair of the Victorian hard defences [3]. This legacy has evolved to embrace various protection measures such as gabions, groynes, revetments and rock armour, in an attempt to lessen the monotonous wave energy impacts, reduce overtopping and subsequent flooding of the hinterlands [3]. After the 1953 storm-surge and isolated surges throughout the last few decades, hard defences have been used as standard following public expectations for urban coastal defence. Additionally since 1994, the Lincolnshire coastal District Councils have employed a rolling five year beach nourishment programme to increase beach levels and provide a stable profile against rising sea levels [8] albeit at ever increasing costs [9].

Over many years, the Netherlands also adopted hard defensive measures in the form of dykes and dune stabilization which has undergone an intensive regeneration programme since 1953 [10]. However, since 1990 and a change in policy, greater emphasis has been placed on the building of various barriers, increase in dam heights and dyke strengthening [11, 12] in an attempt to establish a protective wall along the coast as part of the 'Hold the Line' (HtL) policy. With formalization of this policy [13], rolling five yearly beach nourishment processes came once again to the fore of coastal protection and in 2011, it was replaced by a mega-nourishment conceptual project, turning a costly, time-consuming and cyclic nourishment programme into an innovative, cost efficient and most importantly environmentally sustainable 20 year project.

By the end of the 20th century increases in 'soft' coastal engineering implementations as part of flood and coastal erosion risk management by lead local authorities has resulted in an increase in marine aggregate dredging by the coastal countries surrounding the North Sea. The UK Lincshore scheme by 2013 has extracted over $19 \times 10^{6}$ tonnes of sand from the seabed over its current 20 year project span [9]. This is put into perspective by the larger South Holland sand-motor scheme that has extracted $19.4 \times 10^{6}$ tonnes for coastal management in 2013 alone [14]. Both ecology and seabed are subject to constant physical disturbances from tidal flows and currents, as well as constant biological variations such as the migration of fauna, which are only increased by the dynamics of fishing and mineral extraction be it oil, gas or aggregate $[15,16]$. 
Continued maintenance costs also place increased pressure on the coastal authorities to devise sustainable solutions for coastal protection [13] which prompted development a monitoring and performance evaluation programme as part of national statute to study seabed disturbance in the Netherlands [13].

The aim of this paper is to compare beach nourishment processes. The objectives of this paper where to establish whether mega-nourishment is sustainable over the long-term by conducting interviews and field studies with respective coastal management authorities of North Norfolk District Council (NNDC) and Rijkswaterstaat (RWS). A literature review was conducted to compare the two main approaches of beach nourishment and how these effects associated coastal management.

\section{Methodology}

To achieve the aims and objectives above a qualitative research methodology was applied in establishing background data for this paper. Relying on a mixed method approach various contributions to our research came from expert opinion, peer reviewed literature, project evaluations, and site visits and inspections [17].

A number of stakeholders such as NNDC and RWS, where contacted for background information, employee interviews, and technical advice. This was combined with a literature review of local authority documents and published peer-reviewed literature. Field trips were also conducted to the respective Lincolnshire, South Holland, and North Norfolk coastlines to observe the various coastal management practices of anthropogenic hard and soft interventions react and influence (or are influenced by) the natural processes. The field trips, combined with interviews with the coastal manager and team at North Norfolk District Council, the 'Rivers, Deltares and Coast' team at Royal Haskoning DHV, and a lecturer from Utrecht University have provided an understanding of how the beach nourishment methods of rolling and mega-nourishment programmes compare and the respective effectiveness of reducing the erosion potential whilst ultimately benefiting the coastal zone habitat providing a secure socioeconomic base for the local population [18].

This mixed method approach was considered the most appropriate because it allowed for a flexible interpretation and comparison of expert opinions and literature with policy and best practice industry guidelines. Especially as the concept of mega-nourishment is new there are as yet no academic papers published; with a number of papers are expected to be published from January 2016 following the analysis of the first five years, hence expert opinion has been the key research source of data. This method also provided a multi-objective analysis with a rounded analysis of data rather than one-dimensional thinking that may be found in applying a single method approach [19].

\section{Results and analysis}

The concept of beach nourishment over an extended coastline should be able to provide the security of defence to both urban and agricultural infrastructure as 
well as the habitats of the coastal zone. Beach nourishment can be applied in both a primary defensive way to nurture the coast or as an additional protection measure for anthropogenic structures to reduce the associated maintenance costs and ensure environmental sustainability [20,21]. By extending the gradient of the beach profile through increased nourishment wave energy is dissipated more effectively resulting in the decreased potential to cause coastal erosion and overtopping. With an increase in beach height and width the socio-economic and ecological benefits are many and varied; from the provision of recreational space to hinterland security from erosion and inundation, allowing nature to flourish alongside a vibrant thriving community with guaranteed income from tourism and recreation. Examples of this are of Skegness, Ingoldmells, Mablethorpe, (all in UK), Ter Heijde, Scheveningen and Zandvoort (all in South Holland) have generated improved socio-economics by having an expansive beach system.

Irrespective of the application of beach nourishment methods for either an individual authority (Lincolnshire - ELDC) or a provincial frontage such as South Holland, the beach nourishment project - whether rolling over five years or a mega-nourishment programme is expected to meet and must conform to the Water Framework Directive (WFD), Habitats directive and water Equality Quality Standards Directive (EQSD). This is especially important for areas of coast that straddle a border - be it regional (Lincolnshire/Norfolk) or national (Netherlands/Belgium). In order to achieve this, the programme administrators and coastal managers must ensure both the compliance and application of an effective integrated coastal zone management (ICZM) [10].

Furthermore, for beach nourishment projects to be environmentally sustainable, the stakeholders must rely on sustainably sourced sediment material irrespective of the dredging frequency adopted - which poses and environmental problem. It has been acknowledged [22, 23] that marine dredging temporally destroys the seabed habitat. However, a contentious point is raised by this as to what is the acceptable seabed standard for ecological recovery rates. Estimates range from several months to 15 years due to various marine dynamics it is difficult to determine [24]. This is evident from the lack of literature available to support the physical and biological regeneration cycles of the seabed.

When an evaluation of the typical rolling five year nourishment 'Lincshore' programme adopted by ELDC to provide beach nourishment between Skegness and Mablethorpe, is compared directly against the Sand-motor meganourishment innovative pilot project along the South Holland coastline and is expected to last 20 years without any direct modifications being made, by using an annual calculation (Table 1) of these two nourishments over equivalent project lifetimes it is no surprise that mega-nourishment is both cost effective and environmentally sustainable.

Similarly, there is little difference in the project costs of rolling nourishment compared to continued hard defence maintenance [10]. However, meganourishment projects are estimated to cost half as much as the traditional rolling nourishment schemes and is supported by the direct comparison of study area beach nourishment in Table $1[9,25]$. The benefits, cost savings and 
socioeconomic value from a combination of an extended beach profile and the provision of an amenity value to the local area whilst reducing coastal erosion rates is significant $[9,25]$.

Figure 2 shows the post-storm damage to the hard defense structures recorded during the field trips undertaken for this study. This shows that there may have been omissions on the design of the structures where the effects of climate change may have not been taken into account, and the effectiveness of such structures and measures may be limited due to changing loads. Durability and reliability of these measures in light of the potential climate change effects would have to be included in the design codes, potentially modeled and validated before construction. Additionally, the effect of the structure on the environment and the cost-benefit analysis of the impact on the society would have to be taken into account under a sustainability framework. The design and construction of these measures in the future may be expensive due to the above concerns and they may not be the most viable option for coastal protection.

Table 1: Direct comparison between Lincshore and South Holland programmes over set periods [9, 25].

\begin{tabular}{|c|c|c|c|c|c|c|}
\hline \multirow{2}{*}{$\begin{array}{l}\text { Comparison } \\
\text { variable }\end{array}$} & \multicolumn{6}{|c|}{ Nourishment type } \\
\hline & Rolling & Mega & Rolling & Mega & Rolling & Mega \\
\hline $\begin{array}{l}\text { Sediment quantity } \\
\text { (tonnes) }\end{array}$ & $15.1 \times 10^{6}$ & $21 \times 10^{6}$ & $60.4 \times 10^{6}$ & $21 \times 10^{6}$ & $503 \times 10^{3} / \mathrm{km}$ & $350 \times 10^{3} / \mathrm{km}$ \\
\hline $\begin{array}{l}\text { Cost equivalent } \\
(€ \text { Millions) }\end{array}$ & 42 & 80 & 168 & 80 & 9 & 4 \\
\hline $\begin{array}{l}\text { Renourishment } \\
\text { period (years) }\end{array}$ & 5 & 20 & 20 & 20 & 1 & 1 \\
\hline
\end{tabular}

It is evident from the interviews with various stakeholders, analysis of data (Table 1), and post nourishment observations (Figures 1 and 3), that a combined approach to ensuring that the seabed habitat is exploited in a sustainable way. EU legislation makes it clear for stakeholders to minimise their respective environmental impacts through adopting and adhering to the many and varied directives [35] there is no integrated approach to seabed habitat management. For beach nourishment adaptation to be successful irrespective of employing a rolling or mega-nourishment programme the ability to share research data and minimise seabed disturbance is required.

The 'little and often' rolling nourishment approach is currently considered to be best practice [10], especially as it allows the public to witness over the short term how funds are being spent against immediate success rates even though nourishments are sometimes perceived to be unsuccessful [26]. However, this best practice methodology requires an overhaul; the sand-motor, using a relative new concept of mega-nourishment not only offers a solution to combat coastal erosion, but adds an amenity value to the community with improved overall environmental sustainability. Several authors (for review see [27]) define this combined approach in delivering socio-economic benefits, ecosystem sustainability through resource management, and coordinated stakeholder engagement as 'Integrated Environmental Management'. 
The amount of sediment needed to be dredged in order to implement the nourishment programmes (Table 1), shows how disturbing these measures can be for the seabed and sea life and a rolling nourishment concept limits seabed habitat regeneration, especially when the same locations are dredged repeatedly over several years.

Field trips (Figure 1) show that the beach levels have remained at a good height for the four months since beach nourishment, indicating an expansive shallow inclined beach. This helps to reduce the wave energy at high tide and therefore provide protection to the dune and seafront areas parallel to the beach.

View South

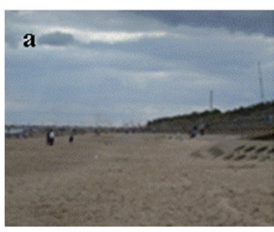

b

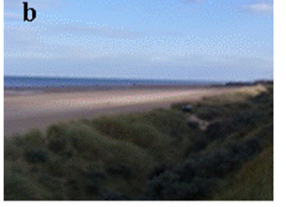

View North
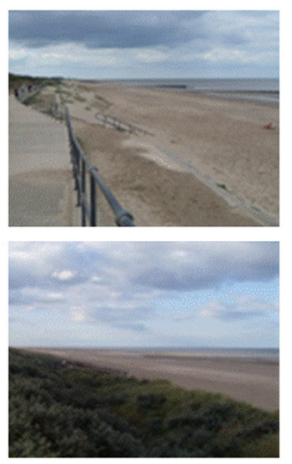

View South

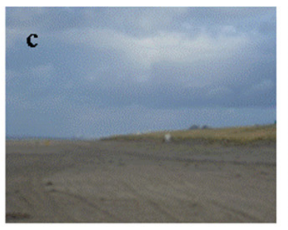

d

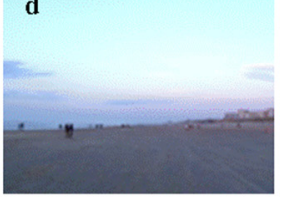

View North
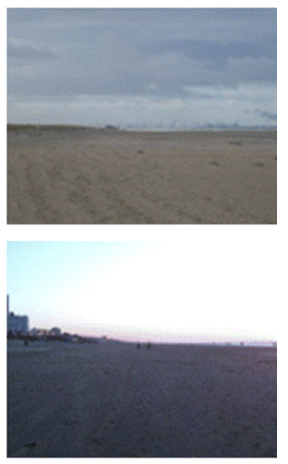

Figure 1: Examples of nourished beach sections in the UK: (a) Skegness, (b) Meers Bank and South Holland, (c) Ter Heijde and (d) Zandvoort.

Hard defense structures were recorded at the study locations. These included various types of seawall, rock armour, groynes, and gabions. The advantages of hard defences are the visible and tangible security to the local community that both land and property are defended. Whereas the disadvantages to hard defences are that historically construction has been built-up without consideration for neighbouring effects and coastal squeeze [28] brought about by the gradual encroachment of urbanization upon the natural habitat combined with the inflexibility of hard defences to adjust to seasonal variations which ironically exacerbate the erosion that the defences were originally built prevent [29]. To counterbalance this, hard defences have been employed together with the soft approaches of dune management, beach nourishment, and in some cases managed realignment [28]. However, some damage has been recorded due to lack of or no maintenance and the effects of the external loads from hydraulic action and corrosion (Figure 2).

The study field trips to observe coastal areas of the Lincshore between Skegness and Mablethorpe highlighted the effectiveness beach nourishment are both in terms of cost savings and reduced erosion risk. By using the rolling programme of beach nourishment the Lincshore coastal defense project provides a large expanse of flat beach profile that is appealing to recreational users. With 
the small volumes $\left(5 \times 10^{5} \mathrm{~m}^{3}\right)$ distributed along the coast annually over the spring ensure summer tourist revenues generating over $€ 0.5 \mathrm{M}$ for the coming holiday season even at a cost of $€ 8 \mathrm{M}$ per annum helps to protect the hinterland flood risk at assets of over $€ 4 \mathrm{Bn}[10]$. When compared to the annual cost of maintaining hard defenses, beach nourishment would appear to be non-cost effective, but once beach nourishment provides security from a 1 in 200 year flood risk opposed to the average of 1 in 10 year breach or 1 in 25 year total failure that is expected from hard defenses [30] as witnessed in Norfolk following the December 2013 storm-surge (Figure 2). In this respect beach nourishment significantly outweighs hard defence protection. The annual cost of funding capital maintenance projects will only increase and will not be made any easier with local authorities having to justify policy spending, although this is being offset by the controversial decision of managed retreat rather than infrastructure maintenance management [31].

The Netherlands coastal protection policy of ensuring that the coastline is maintained at its 1990 position justifies the application of mega-nourishment to provide protection for all urban and rural coastal sections along South Holland coastline and the respective hinterland [32] at a fraction of the total cost when compared to the Lincshore budget in Table 1. This was highlighted during the study trip to observe the effects and implications of the sand-motor in the winter of 2014. When even at that time of year, three and a half years post nourishment the beaches remained in good condition, with a gentle sloping profile able to provide expansive areas for recreation, habitat preservation and effective waveenergy dissipation.
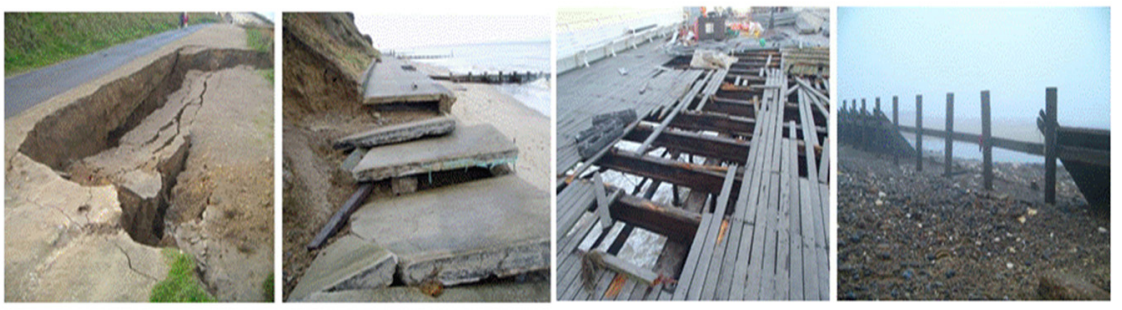

Figure 2: $\quad$ Post storm-surge damage to various NNDC coastal assets.

The use of groynes in theory offers the potential for sediment capture opportunities along a stretch of beach. However, depending on how longshore and cross-shore drift affects the movement of material along the beach, combined with the length, spacing and angle of the groyne system as well as the type of groyne construction all contribute to determine how effectively sediment material is trapped within the groyne bays [31]. Therefore the natural generation of a regular beach profile is variable especially when relying on natural processes or annual nourishments. Figure 3 best illustrates the pre and post nourishment effects at Mablethorpe on the Lincshore project. 

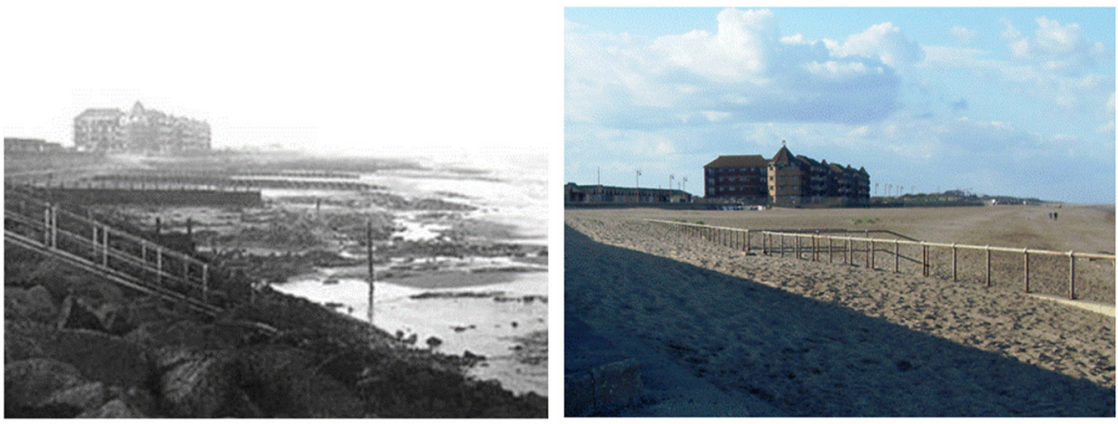

Figure 3: Pre [9] and post nourishment examples at Mablethorpe, Lincolnshire.

The 'pre-nourishment' photograph taken in 1997 is three years after the commencement of the Lincshore project and illustrates the ineffectiveness of hard defences to capture and retain beach material. Conversely, the "postnourishment' photograph taken in 2014 displays a gradual improvement in beach levels whilst maintaining the seawall toe of the Mablethorpe frontage, there is however visible contour scouring. Although, an annual sediment deposit is required to balance the net losses in reducing potential flood events of overtopping or breaching and to provide equilibrium on the cyclic effects of beach lowering [33] this illustrates the effectiveness of adapting beach nourishment programmes. This in turn provides protection against toe scour of the seawall structures as observed along the Lincshore frontage at Skegness, Ingoldmells, Chapel St Leonards, and Mablethorpe (all in UK), and at Scheveningen and Zandvoort (in South Holland).

Although a rolling beach nourishment programme offers improved coastal protection than that of anthropogenic defenses, the adaptation and use of a meganourishment scheme would vastly improve the overall management of the frontage. This was observed at Ter Heijde where the sand-motor, even after four years post inception is still developing and molding to the natural processes of the coast whilst providing a benefit to the local economy and ecology. With similar beach gradient profiles between Lincshore and South Holland, the frontage between Ter Heijde and Zandvoort resembled a more natural beach profile with no indication of scour along the frontage as was witnessed at Skegness during the field trip observations.

Field trips undertaken for this study before and after the application of beach nourishment methods show stable beach profiles approximately two months after the last beach nourishment programme had completed (Lincshore, Figure 1(a)) and 36 months after the start of the sand-motor project at Ter Heijde (Figure 1(c)). Both of these measures validate the effectiveness of the approaches with the difference that at Lincshore the nourishment programmes are implemented every five years and the mega-nourishment programme in South Holland was employed once. 
The interviews with relevant stakeholders supported the findings from the literature (Table 1). Current funding requirements revolve around protecting assets from loss rather than being suitably and sustainably managed [34]. For North Norfolk this equates to maintaining the hard defences of strategic tourist areas such as Cromer and Sheringham with an increase in utilising rock armour to provide additional seawall protection. The cost of maintain the hard defences is increasing and so is a major factor in justification of approach. Funding is obtained through a central government partnership funding calculator but with an ever greater percentage input required by the local authority. This means that the majority of large projects are increasingly being funded through third parties with coastal protection assets becoming a tangible commodity. Even national assets such as Bacton gas terminal in Norfolk or the Theddlethorpe gas terminal at Mablethorpe require continued assessment to justify sustained investment as a result of the changes imposed on the natural habitat by introducing additional sediment [34]. Sustainable beach nourishment projects helps to generate income locally by increasing tourism whilst maintaining the appeal and accessibility of the general public as can be witnessed at Sea Palling (Norfolk, UK) and the caravan parks at Ingoldmells along the Lincshore, in addition to the benefit in supporting and increasing biodiversity [34].

Both of the locations have had seawall structures installed in the past that have required repairs or have been decommissioned to maintain public safety. However, because of the increased costs of continued repair and maintenance of the structures, the nourishment methods were adopted with success at both locations. Although a rolling cyclic nourishment programme can be as expensive as hard defences to maintain over a corresponding period [8].

In response to an integrated management approach coastal concordats are being to be embraced by local authorities as part of integrated coastal zone management [34]. This improves the availability of knowledge resources required to manage the coastal zone efficiently and sustainably whilst increasing the prospect of securing additional funding. It also ensures that all stakeholders are working towards a sustainable coast by reporting to a designated lead authority which can oversee correct WFD and habitat assessment commitments.

To meet the criteria of various EU directives - WFD, Habitat, Floods, Natura 2000 and MSFD, a more generic framework for effective ICZM is required [10]. This in part has been achieved over the last decade (since 2002) but without an integrated research approach for best practice habitat regeneration [35]. For an ICZM to be effective, both political acceptance and a public understanding of the effects from climate change and coastal erosion are required [36]. A public education role provided by coastal authorities should be considered to ensure a sustainable ecological balance with effective and efficient ICZM.

Even though beach nourishment is an effective method in stabilizing and reducing coastal erosion a greater public awareness is required concerning the intangible benefits of renourishment. It is therefore the responsibility of local authorities to promote and educate the sand-motor positives which contribute to an essential coast protection function. The collected research would provide other countries the confidence to reduce coastal squeeze and enhancing the 
environment through mega-nourishment rather than maintaining hard defences at ever spiraling costs [31].

\section{Conclusion}

The concept of soft engineering projects such as beach nourishment are both an effective, sustainable, and flexible choice for coastal managers in providing protection against SLR and erosion [36]. This is in comparison to hard defences where they are becoming increasingly more difficult modify to combat SLR and the effects of erosion [33].

The sand-motor research currently being conducted in the Netherlands will provide a valuable data source of mega-nourishment dynamics for coastal managers of local authorities to enable them to evaluate with an integrated approach rather than the current industry-driven 'silo' management method of individual sections require different solutions $[12,33]$.

It is recommended that mega-nourishments programmes should be considered as alternatives to hard engineering defences and the soft engineering methods of managed realignment by all coastal authorities and managers.

\section{Acknowledgements}

We would like to thank and are grateful to the contributions and interviews from individuals and Organisations namely, R. Goodliffe, A. McCloud, and B. Farrow (NNDC), M. Russell (BMAPA), S. Cowper and J. Stoutt (Eastern IFCA), G. Ramaekers (RWS) and L.P.H. van Beek (Utrecht University).

\section{References}

[1] Evans, E., Ashley, R., Hall, J., Penning-Rowsell, E., Saul, A., Sayers, P., Thorne, C. \& Watkinson, A., Foresight: Future flooding scientific summary volume 1 - future risks and there drivers. Office of Science and Technology, London p. 1, 2004.

[2] Komar, P.D., Coastal erosion processes and impacts: The consequences of Earth's changing climate and human modifications of the environment (Chapter 3). Treatise on estuarine and coastal science, ed. E. Wolanski \& D. McLusky, Academic Press, Waltham, pp. 285-308, 2011.

[3] Frew, P., An introduction to the North Norfolk coastal environment, North Norfolk District Council, Cromer, 2009.

[4] Ducrotoy, J., \& Elliott, M., "The science and management of the North Sea and the Baltic Sea: Natural history, present threats and future challenges", Marine Pollution Bulletin, Vol. 57, pp. 8-21, 2008.

[5] Cook, G.S., Fletcher, P.J. \& Kelble, C.R., "Towards marine ecosystem based management in south Florida: Investigating the connections among ecosystem pressures, states, and services in a complex coastal system", Ecological Indicators, Vol. 44, pp. 26-39, 2014. 
[6] Brammer, H., "Bangladesh's dynamic coastal regions and sea-level rise", Climate Risk Management, Vol. 1, pp. 51-62, 2014.

[7] de Ruig, J.H.M., "Coastline management in the Netherlands: Human use versus natural dynamics", Journal of Coastal Conservation, Vol. 4, pp. 127-134, 1998.

[8] van de Graaff, J., Niemeyer, H.D. \& van Overeem, J., "Beach nourishment, philosophy and coastal protection policy", Coastal Engineering, Vol. 16, no. 1, pp. 3-22, 1991.

[9] Rouse, A.E., Stockwell, V., Mead, C., Cali, M., \& Harris, B., Adapting to climate change on the Lincolnshire coastline through the Lincshore beach management scheme. Environment Agency, Peterborough, 2013.

[10] Marchand, M., Concepts and science for coastal erosion management. Concise report for policy makers. Deltares, Delft, 2010.

[11] de Vries, M., Diverse dike. (004), Deltares, Delft, Netherlands, 2009.

[12] Eversdijk, P.J., \& Stefess, H., Coast protection - water retaining structures in the Netherlands. (Kaz-N-93022), Rijkswaterstaat, Utrecht, 1993.

[13] Hanson, H., Brampton, A., Capobianco, M., Dette, H.H., Hamm, L., Laustrup, C., Lechuga, A., \& Spanhoff, R., "Beach nourishment projects, practices, and objectives - a European overview", Coastal Engineering, Vol. 47, no. 2, pp. 81-111, 2002.

[14] ICES., First interim report of the working group on the effects of extraction of marine sediments on the marine ecosystem (WGEXT). (CM2014/SSGHIE:07), International Council for the Exploration of the Sea, Reykjavik, Iceland, 2014.

[15] Smith, R., Boyd, S.E., Rees, H.L., Dearnaley, M.P. \& Stevenson, J.R., "Effects of dredging activity on epifaunal communities - surveys following cessation of dredging", Estuarine, Coastal and Shelf Science, Vol. 70, no. 1-2, pp. 207-223, 2006.

[16] Cooper, K.M., Froján, C.R.S.B., Defew, E., Curtis, M., Fleddum, A., Brooks, L. \& Paterson, D.M., "Assessment of ecosystem function following marine aggregate dredging”, Journal of Experimental Marine Biology and Ecology, Vol. 366, no. 1-2, pp. 82-91, 2008.

[17] Layder, D., Doing excellent small scale research, Sage, London, 2013.

[18] Hart, C., Doing a literature review, Sage, London, 1998.

[19] Zou, P.X.W., Sunindijo, R.Y. \& Dainty, A.R.J., "A mixed methods research design for bridging the gap between research and practice in construction safety", Safety Science, Vol. 70, pp. 316-326, 2014.

[20] Bird, E.C.F., Beach management, Wiley \& Sons, Chichester, 1996.

[21] Hamm, L., Capobianco, M., Dette, H.H., Lechuga, A., Spanhoff, R. \& Stive, M.J.F., "A summary of European experience with shore nourishment”, Coastal Engineering, Vol. 47, pp. 237, 2002.

[22] Newell, R.C., Seiderer, L.J. \& Hitchcock, D.R., "The impact of dredging works in coastal waters: A review of the sensitivity to disturbance and subsequent recovery of biological resources on the sea bed", Oceanography and Marine Biology, Vol. 36, pp. 127-178, 1998. 
[23] Bray, R.N., Environmental aspects of dredging, CRC Press, London, 2008.

[24] Hill, J.M., Marzialetti, S. \& Pearce, B., Recovery of seabed resources following marine aggregate extraction. (2-MEPF10/P148), MASLF, Bath, 2011.

[25] RWS (Rijkswaterstaat)., in press information leaflets - The Sand Motor: Looking back at 21/2 years of building with nature translated from Zandmotor Delflandse Kust Een blik op 2,5 jaar bouwen met de natuur, Rijkswaterstaat, Netherlands, 2013.

[26] Verhagen, H.J., "Method for artificial beach nourishment", Coastal Engineering, pp. 2474-2485, 1992.

[27] Manap, N., \& Voulvoulis, N., "Environmental management for dredging sediments - the requirement of developing nations", Journal of Environmental Management, pp. 1-11, 2014.

[28] French, P.W., Coastal and estuarine management, Routledge, London, 1997.

[29] van Rijn, L.C., "Coastal erosion and control”, Ocean \& Coastal Management, Vol. 54, no. 12, pp. 867-887, 2011.

[30] Mead, C., Sandy solution for reducing flood risk in Lincolnshire: Coastal management projects. Royal Haskoning DHV, Peterborough, 2014.

[31] Dales, D., Evans, L., Short, J., Mitchell, L., \& Pos, J. 2010, Humber Estuary Coastal Authorities Group (HECAG). SMP3: Flamborough Head to Gibraltar Point shoreline management plan. Scott Wilson, 2010.

[32] Mulder, J.P.M., Hommes, S. \& Horstman, E.M., "Implementation of coastal erosion management in the Netherlands", Ocean \& Coastal Management, Vol. 54, no. 12, pp. 888-897, 2011.

[33] van Oorschot, J.H. \& van Raalte, G.H., "Beach nourishment; execution methods and developments in technology", Coastal Engineering, Vol. 16, no. 1, pp. 23-42, 1991.

[34] Goodliffe, R., Personal communication, 08 July 2014, Coastal Manager, North Norfolk District Council, Cromer, UK.

[35] Vanstaen, K., Limpenny, D., Lee, J., Eggleton, J., Brown, A., Stelzenmüller, V., James, C. \& Rocks, K., "The scale and impact of fishing activities in the Eastern English Channel: an initial assessment based on existing geophysical survey data", CEFAS final contract report, MEPF07/04, 2008.

[36] Beeharry, Y., Makoondlall-Chadee, T. \& Bokhoree, C., "Policy analysis for performance assessment of integrated coastal zone management initiatives for coastal sustainability", APCBEE Procedia, Vol. 9, pp. 30$35,2014$. 